\title{
Prevalence and Public Health Implications of State Laws that Criminalize Potential HIV Exposure in the United States
}

\author{
J. Stan Lehman • Meredith H. Carr • Allison J. Nichol • \\ Alberto Ruisanchez $\cdot$ David W. Knight • Anne E. Langford • \\ Simone C. Gray $\cdot$ Jonathan H. Mermin
}

Published online: 15 March 2014

(C) Springer Science+Business Media New York (outside the USA) 2014

\begin{abstract}
For the past three decades, legislative approaches to prevent HIV transmission have been used at the national, state, and local levels. One punitive legislative approach has been enactment of laws that criminalize behaviors associated with HIV exposure (HIV-specific criminal laws). In the USA, HIV-specific criminal laws have largely been shaped by state laws. These laws impose criminal penalties on persons who know they have HIV and subsequently engage in certain behaviors, most commonly sexual activity without prior disclosure of HIVpositive serostatus. These laws have been subject to intense public debate. Using public health law research methods, data from the legal database WestlawNext $\odot$ were analyzed to describe the prevalence and characteristics of laws that criminalize potential HIV exposure in the 50 states (plus the District of Columbia) and to examine the implications of these laws for public health practice. The first state laws were enacted in 1986; as of 2011 a total of 67 laws had been enacted in 33 states. By 1995, nearly two-thirds of all laws had been enacted; by $2000,85 \%$ of laws had been enacted; and since 2000, an additional 10 laws have been enacted. Twenty-four states require persons who are aware
\end{abstract}

J. S. Lehman $(\varangle) \cdot$ M. H. Carr · S. C. Gray · J. H. Mermin Division of HIV/AIDS Prevention, National Center for HIV/ AIDS, Viral Hepatitis, STD and TB Prevention, Centers for Disease Control and Prevention, 1600 Clifton Rd, MS-D21, 30333 Atlanta, Georgia

e-mail: slehman@cdc.gov

\section{H. Carr}

Oak Ridge Institute for Science and Education (ORISE) fellow, Atlanta, Georgia

A. J. Nichol - A. Ruisanchez - D. W. Knight - A. E. Langford Civil Rights Division, United States Department of Justice, Washington, DC, USA that they have HIV to disclose their status to sexual partners and 14 states require disclosure to needle-sharing partners. Twenty-five states criminalize one or more behaviors that pose a low or negligible risk for HIV transmission. Nearly two-thirds of states in the USA have legislation that criminalizes potential HIV exposure. Many of these laws criminalize behaviors that pose low or negligible risk for HIV transmission. The majority of laws were passed before studies showed that antiretroviral therapy (ART) reduces HIV transmission risk and most laws do not account for HIV prevention measures that reduce transmission risk, such as condom use, ART, or preexposure prophylaxis. States with HIV-specific criminal laws are encouraged to use the findings of this paper to reexamine those laws, assess the laws' alignment with current evidence regarding HIV transmission risk, and consider whether the laws are the best vehicle to achieve their intended purposes.

Keywords HIV prevention · HIV-specific criminal laws · Public health law research - Public health policy .

Structural interventions $\cdot$ State laws

Resumen Durante las últimas tres décadas, se han utilizado a nivel nacional, estatal y local enfoques legislativos para prevenir la transmisión del VIH. Un enfoque legislativo punitivo ha sido la promulgación de leyes que criminalizan conductas asociadas a la exposición al VIH (leyes criminales específicamente relacionadas con el VIH). En los Estados Unidos, las leyes criminales específicamente relacionadas con el VIH han sido en gran medida influenciadas por leyes estatales. Estas leyes imponen sanciones criminales a las personas que saben que tienen el VIH y posteriormente participan en ciertos comportamientos o conductas, frecuentemente la actividades sexuales, sin la 
divulgación previa del estado serológico del VIH. Estas leyes han sido objeto de un intenso debate público. Utilizando métodos de investigación de la ley de salud pública, datos obtenidos de la base de datos legal WestlawNext $\odot$ fueron analizados para describir la prevalencia y las características de las leyes que criminalizan la posible exposición al VIH en los 50 estados de los Estados Unidos y el Distrito de Columbia y examinar las implicaciones de estas leyes en la práctica de salud pública. Las primeras leyes estatales fueron promulgadas en 1986; para el año 2011, un total de 67 leyes se habían promulgado en 33 estados. Para el año 1995, casi dos tercios de todas las leyes habían sido aprobadas; para el año 2000, el $85 \%$ de las leyes habían sido aprobadas; y desde el año 2000, se han aprobado otras 10 leyes adicionales. Veinticuatro estados requieren que las personas que saben que tienen el VIH revelen su condición a sus parejas sexuales y 14 estados requieren divulgación de la condición del VIH a las parejas con quien comparten agujas. Veinticinco estados criminalizan uno o más comportamientos que representan un riesgo bajo o insignificante para la transmisión del VIH. Casi dos tercios de los estados de los Estados Unidos han promulgado legislación que criminalizan la posible exposición al VIH. Muchas de estas leyes penalizan conductas que representan un riesgo bajo o insignificante para la transmisión del VIH. La mayoría de estas leyes se aprobaron antes de que investigaciones conducidas demostraran que la terapia antirretroviral (ART, por sus siglas en inglés) reduce el riesgo de transmisión del VIH y la mayoría no toman en consideración medidas de prevención que reducen el riesgo de transmisión del VIH, tales como el uso del condón, ART, o la profilaxis pre-exposición (PrEP). Se exhorta a los estados que han aprobado leyes criminales específicamente relacionadas con el VIH a utilizar los hallazgos de este trabajo para reexaminar las leyes vigentes, evaluar la alineación de las leyes con la evidencia actual con respecto al riesgo de transmisión del VIH, y considerar si estas leyes son el mejor vehículo para lograr los fines previstos.

\section{Introduction}

Legislative approaches to prevent HIV transmission have been used by federal, state, and local governments since the emergence of the HIV epidemic in the United States in the early 1980s. Strategies have been both protective of, and punitive towards, persons living with $\operatorname{HIV}[1,2]$. For example, on the one hand, changes in state HIV testing laws promoted HIV screening in health care settings [3], and expanded state and federal confidentiality laws protected sensitive health information [4, 5]. On the other hand, some states have used punitive laws to criminalize behaviors that are associated with potential exposure to HIV (defined as HIV-specific criminal laws) [6-8]. HIVspecific criminal laws impose criminal penalties on persons who know that they have HIV and engage in certain behaviors, most commonly sexual activity without prior disclosure of their status. States may also use general criminal laws or communicable disease laws to prosecute persons accused of exposing others to HIV [6-8].

HIV-specific criminal laws are a controversial policy [9, 10] and some prosecutions under them have received widespread local and national media attention [11, 12]. In some cases, prosecutions were based on documented HIV transmission; some were based on behaviors with an increased likelihood of HIV transmission; and others were based on behaviors posing little or only theoretical risk of transmission, such as biting or spitting [11]. Generally, HIV-specific criminal laws do not take into account measures that reduce the risk of HIV transmission [7, 9, 13-15] such as condom use, antiretroviral therapy (ART), or preexposure prophylaxis (PrEP).

The Federal government has periodically provided guidance to states on HIV-specific criminal laws. In 1988, the Report of the Presidential Commission on the Human Immunodeficiency Virus Epidemic stated "criminal sanctions for HIV transmission must be carefully drawn, must be directed only towards behavior which is scientifically established as a mode of transmission, and should be employed only when all other public health and civil actions fail to produce responsible behavior" [16]. In 1990, the Ryan White Comprehensive AIDS Resources Emergency Act (PHL101-881) (federal legislation providing funding to states for AIDS treatment and care), required states to certify that criminal laws were adequate to prosecute individuals who knowingly exposed another person to HIV [17]. By 2010, however, the President's National HIV/AIDS Strategy addressed HIV-specific criminal laws, stating that "in some cases, it may be appropriate for legislators to reconsider whether existing laws continue to further the public interest and public health" [18]. In 2011, an original member of the Commission that authored the 1988 Report stated that it is "probably past time" for states to revisit HIV-specific criminal laws and "subject those laws to scientific scrutiny" [19].

The primary legal justifications put forth for using criminal law to prosecute persons accused of potential HIV exposure are to deter certain behaviors and to impose retributive justice on those engaging in those behaviors [13, 7]. Some research has suggested that HIV-specific criminal laws may not alter behaviors among persons living with HIV [15, 20-22]. In one study comparing persons in a state with HIV-specific criminal laws to persons in a state without such laws, little difference in self-reported sexual behaviors was found, and persons who believed the law 
required safer sex practices or disclosure of HIV status to partners reported little difference in risk behaviors. The authors concluded that these laws did not deter risky behavior and may cause harm by interfering with public health efforts to reach those populations at highest risk of infection [15].

Concerns have been raised in the literature that HIVspecific criminal laws may also increase stigma towards persons living with HIV [2, 7, 8, 13, 14], reduce the likelihood of disclosure to sexual or needle-sharing partners [14], reduce frequency of HIV testing [6, 7] since knowledge of status is required for culpability [7], or lead to inflammatory or ill-informed media coverage that may perpetuate misinformation regarding modes of HIV transmission [13].

Required disclosure of HIV-positive status to sexual partners is a prominent feature of HIV-specific criminal laws. The Centers for Disease Control and Prevention (CDC) recommends that persons living with HIV disclose their HIV status to potential sexual and needle-sharing partners [23], and supports public health strategies to facilitate disclosure. Both the legal and public health strategies are based on the premise that disclosure increases the likelihood of engaging in safer behaviors, and, when implemented effectively, can increase social support for persons with HIV.

A number of national assessments of state-specific criminal laws have been previously published $[7,8,11$, 14]. Each of these raised concern that current state laws criminalize behaviors that pose low or negligible risk for HIV transmission. In order to address this public health concern, we assessed the prevalence and characteristics of state HIV-specific criminal laws and examined their implications for public health practice with a specific focus on elements of the laws that may criminalize behaviors that pose low or negligible risk of HIV transmission. We limited this analysis to HIV-specific criminal laws because (unlike general criminal laws) they pertain only to persons living with HIV who are aware that they carry the virus.

\section{Methods}

To develop a systematic public health law research approach to defining and measuring the public health implications of state laws, CDC's Division of HIV/AIDS Prevention implemented the Legal Assessment Project. The Project systematically assesses statutory and regulatory frameworks across a range of legal domains to assess whether these legal frameworks are barriers or facilitators to effective HIV prevention environments. HIV-specific criminal law is one of the Project's domains.
Within each state's statutory code, laws criminalizing potential HIV exposure can be found in several different sections, including the Health and Safety Code, Criminal Code, Public Health Code, and other areas depending on the particular state code. We assessed state HIV-specific criminal laws by conducting a 50-state (plus the District of Columbia) survey using the comprehensive legal database WestlawNext@. Initial search terms were very broad, including the following:

\{ "HIV," "human immunodeficiency virus," "AIDS," "acquired immunodeficiency syndrome," "sexual! transmit! disease!," "sexual! transmit! infection!," "communicable disease!," and "venereal disease!" \}.

These terms captured the statutes relevant to this analysis. Each captured statute was evaluated individually and only those determined to specifically criminalize potential exposure to HIV by persons aware of their positive serostatus were coded and entered into the analysis database (i.e., laws incurring civil penalties were not examined). Key characteristics of the laws were categorically coded by a trained coder (with independent verification by a second coder). The final analysis database included the enactment year of each law, disclosure requirements, activities prohibited under the law (including sexual activity without disclosure, prostitution/solicitation, blood/tissue/fluid donation, and biting/ spitting/throwing of bodily fluids), most severe degree of punishment under a particular law, and available defenses delineated in the law. The final database included 67 individual laws across 33 states. A number of states have more than one HIV-specific criminal law. Commonly, newly enacted laws addressed different criminalized behaviors from previously enacted laws. The elements of multiple laws in a given state were combined to describe the overall characteristics of HIV-specific criminal laws in that state. Finally, the degree of HIV transmission risk of prohibited behaviors for each state was then categorized based on the estimated per-act probability of acquiring HIV from an infected source [24]. Data were collected, coded and analyzed using public health law research methods [25-27].

\section{Results}

\section{Enactment History}

Currently, there are 33 states that have one or more HIVspecific criminal laws. In 1986 the first HIV-specific criminal laws were enacted in Florida, Tennessee, and Washington, and by 2011 a total of 67 laws had been enacted (Fig. 1). A number of states have passed multiple laws with HIV-specific criminal content (including amendments to previous statutes that substantially modified the text of a law in a way that changed its overall characteristics). In 


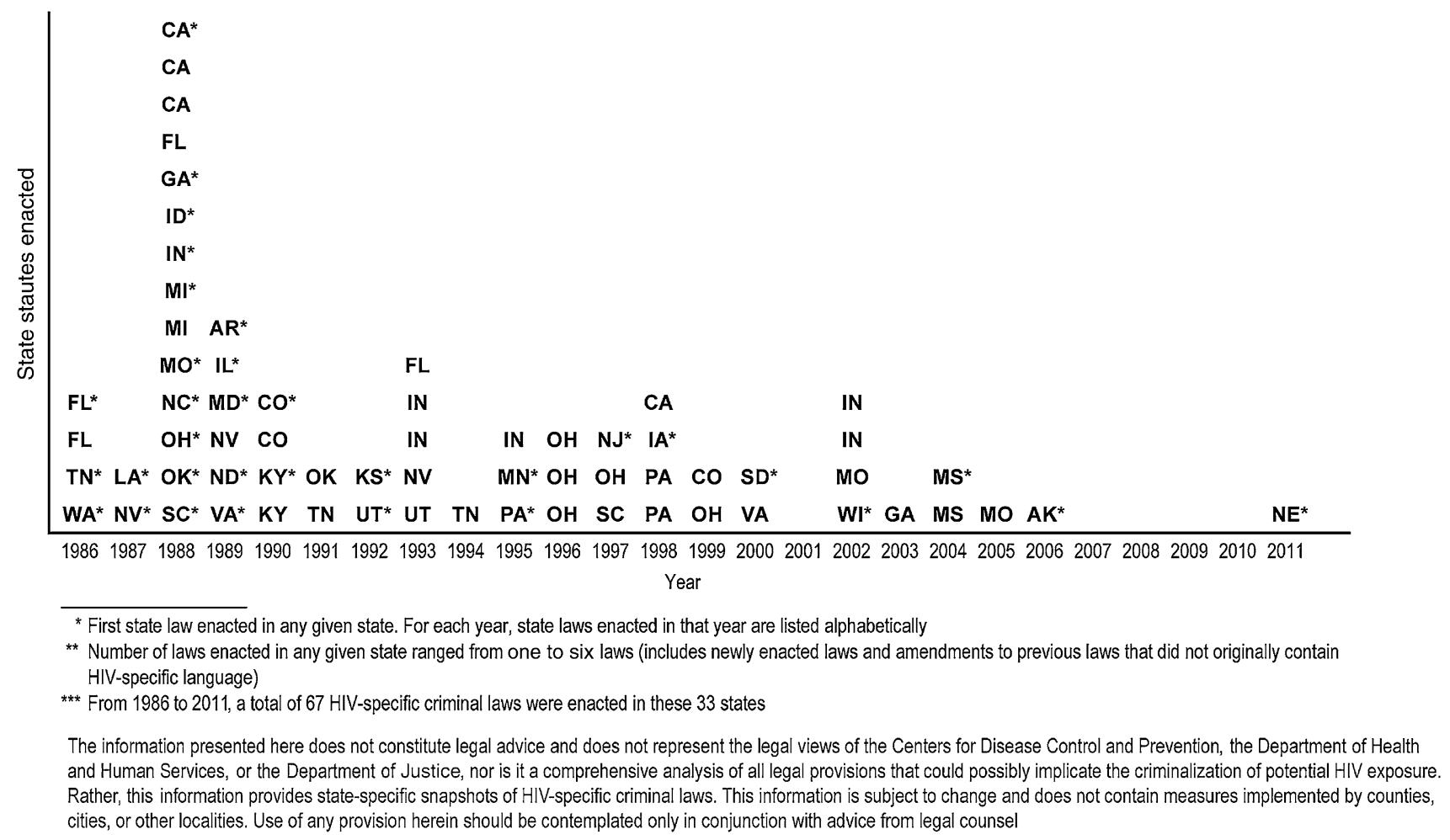

Fig. 1 Enactment of state laws that criminalize potential HIV exposure in 33 states-1986-2011***

some cases, we included amendments to previous laws that did not originally contain HIV-specific language. Enactment of new laws has declined over time. Overall, twothirds (22 of 33) of states enacted their first law from 1986 to 1990 ; by 1995 , more than three-fourths (26 of 33) of states had enacted their first law; and by 2000 , nearly $90 \%$ (29 of 33) of states had passed their first law. Since 2000, the remaining four states enacted their first law.

\section{Disclosure and Criminalized Behaviors}

Of the 33 states with HIV-specific criminal laws, 24 require persons who are aware that they have HIV to disclose their status to sexual partners (Table 1). Fourteen of these 24 states also require disclosure to needle-sharing partners. Among the 33 states, 13 criminalize prostitution/solicitation; 11 criminalize behaviors such as biting, spitting, and throwing bodily fluids, most often in the context of prisons and correctional facilities; 19 criminalize donating blood, tissue, or bodily fluids; and five impose sentence enhancement for sexual offenses (Table 1).

\section{Level of HIV Transmission Risk}

We categorized criminalized behaviors by the level of HIV transmission risk [24], without accounting for prevention measures, such as condom use, ART, or PrEP, that reduce the likelihood of transmission. Twenty-seven of 33 states specifically criminalize one or more behaviors that pose a high risk of HIV transmission, including anal and vaginal sex; prostitution; and donation of blood, tissues, and other bodily fluids. Twenty-five of 33 states criminalize one or more behaviors that pose a low risk for HIV transmission, including oral sex (21 states), or behaviors posing negligible risk, including biting, spitting, or throwing bodily fluids at another individual (11 states) (Fig. 2). Thirteen states impose additional criminal liability for prostitution by individuals with HIV, regardless of the risk of the behaviors engaged in by those individuals. In some states, we interpreted general language about sexual contact or sexual conduct to include oral, vaginal, or anal sex even though those acts were not explicitly listed. Some states did not identify any specific behaviors criminalized. For example, Maryland's statute broadly states that a defendant "may not knowingly transfer or attempt to transfer" HIV to another individual [28].

\section{Degree of Punishment}

HIV-specific criminal laws are classified as felonies in 28 states; in three states, a person's exposure of another to HIV does not subject the person to criminal prosecution for that act alone, but may result in a sentence enhancement or it may be considered an aggravating factor if the person is prosecuted for a related crime; and two states (North Carolina and Maryland) classify the crime as only a misdemeanor and impose a less severe punishment (Appendix). We analyzed 
Table 1 Characteristics of laws that criminalize potential HIV exposure in 33 states $^{\mathrm{a}}$

\begin{tabular}{|c|c|c|c|}
\hline Key statutory characteristics ${ }^{b}$ & $\begin{array}{l}\text { \# of } \\
\text { states }\end{array}$ & $\begin{array}{l}\text { Percentage } \\
(\%)\end{array}$ & States \\
\hline \multicolumn{4}{|l|}{ Disclosure requirements } \\
\hline To sex partners & 24 & 73 & $\begin{array}{l}\text { AR, CA, FL, GA, IA, ID, IL, IN, KS, LA, MI, MN, MO, MS, } \\
\text { NC, ND, NJ, NV, OH, OK, SC SD, TN, VA }\end{array}$ \\
\hline To needle-sharing partners & 14 & 42 & GA, IA, ID, IL, IN, KS, MN, MO, NC, ND, OK, SC, SD, TN \\
\hline Sentence enhancement & 5 & 15 & $\mathrm{AK}, \mathrm{CA}, \mathrm{CO}, \mathrm{FL}, \mathrm{WI}$ \\
\hline \multicolumn{4}{|l|}{ Maximum sentence length } \\
\hline Up to 10 years & 18 & 55 & $\begin{array}{l}\text { CA, CO, FL, IL, KS, KY, MD, MI, MS, NC, NE, NJ, NV, OH, } \\
\text { OK, PA, UT, VA }\end{array}$ \\
\hline $11-20$ years & 7 & 21 & $\mathrm{GA}, \mathrm{ID}, \mathrm{LA}, \mathrm{ND}, \mathrm{SC}, \mathrm{SD}, \mathrm{TN}$ \\
\hline Greater than 20 years & 5 & 15 & AR, IA, IN, MO, WA \\
\hline Not explicitly quantified & 3 & 9 & $\mathrm{AK}, \mathrm{MN}, \mathrm{WI}$ \\
\hline \multicolumn{4}{|l|}{ Potential transmission behaviors criminalized } \\
\hline Donation of blood, tissues, and fluids & 19 & 58 & $\begin{array}{l}\text { AR, CA, FL, GA, IA, ID, IL, IN, KS, KY, MI, MN, MO, NC, } \\
\text { OH, SC, SD, TN, VA }\end{array}$ \\
\hline Prostitution/solicitation & 13 & 39 & CA, CO, FL, GA, KY, MO, NV, OH, OK, PA, SC, TN, UT \\
\hline Biting/spitting/throwing ${ }^{\mathrm{c}}$ & 11 & 33 & GA, IN, LA, MO, MS, NE, OH, PA, SC, SD, UT \\
\hline Mutual masturbation $^{\mathrm{c}}$ & 1 & 3 & $\mathrm{CO}$ \\
\hline Sharing sex objects & 4 & 12 & AR, MI, MN, NJ \\
\hline Oral $\operatorname{sex}^{\mathrm{c}, \mathrm{d}}$ & 21 & 64 & $\begin{array}{l}\text { AR, CO, FL, GA, IA, ID, IL, IN, LA, MI, MN, MO, NC, ND, } \\
\text { NJ, OH, OK, SC, SD, TN, VA }\end{array}$ \\
\hline Vaginal sex ${ }^{\mathrm{d}}$ & 24 & 73 & $\begin{array}{l}\text { AR, CA, CO, FL, GA, IA, ID, IL, IN, KS, KY, LA, MI, MN, } \\
\text { MO, NC, ND, NJ, OH, OK, SC, SD, TN, VA }\end{array}$ \\
\hline Anal sex ${ }^{\mathrm{d}}$ & 24 & 73 & $\begin{array}{l}\mathrm{AR}, \mathrm{CA}, \mathrm{CO}, \mathrm{FL}, \mathrm{GA}, \mathrm{IA}, \mathrm{ID}, \mathrm{IL}, \mathrm{IN}, \mathrm{KS}, \mathrm{KY}, \mathrm{LA}, \mathrm{MI}, \mathrm{MN} \text {, } \\
\mathrm{MO}, \mathrm{NC}, \mathrm{ND}, \mathrm{NJ}, \mathrm{OH}, \mathrm{OK}, \mathrm{SC}, \mathrm{SD}, \mathrm{TN}, \mathrm{VA}\end{array}$ \\
\hline \multicolumn{4}{|l|}{ Defenses } \\
\hline $\begin{array}{l}\text { Disclosure (with burden of proof of } \\
\text { lack of disclosure on prosecution) }\end{array}$ & 16 & 48 & $\begin{array}{l}\text { AR, CA, FL, GA, IN, KS, LA, MI, MN, MO, NC, NJ, OH, OK, } \\
\text { SC, VA }\end{array}$ \\
\hline Disclosure (as an affirmative defense) & 8 & 24 & IA, ID, IL, MS, ND, NV, SD, TN \\
\hline Condom use & 4 & 12 & $\mathrm{CA}, \mathrm{MN}, \mathrm{NC}, \mathrm{ND}$ \\
\hline Total & 33 & 100 & \\
\hline
\end{tabular}

The information presented here does not constitute legal advice and does not represent the legal views of the Centers for Disease Control and Prevention, the Department of Health and Human Services, or the Department of Justice, nor is it a comprehensive analysis of all legal provisions that could possibly implicate the criminalization of potential HIV exposure. Rather, this information provides a state-specific snapshot of HIVspecific criminal laws. This information is subject to change and final determination of state level characteristics of the law can only be made by a given state's legal counsel. Use of any provision herein should be contemplated only in conjunction with advice from legal counsel

${ }^{a}$ Data presented in this table represent the cumulative characteristics of all HIV-specific criminal laws in each state

${ }^{b}$ A given statute may address any of the statutory characteristics included in this table

c These characteristics of HIV-specific criminal laws are defined as low risk (oral sex) or negligible risk (biting/spitting/throwing bodily fluids, mutual masturbation)

${ }^{\mathrm{d}}$ Most HIV-specific criminal laws in these groups specifically include oral, vaginal, or anal sex. In a few states, very general language about sexual contact or sexual conduct was interpreted for the purpose of this analysis to include oral, vaginal, or anal sex even though not specifically mentioned. Two states (MD and NV) included no language about transmission behaviors

the length of prison sentences, rather than severity level (such as Class A Felony, Level II Felony, etc.), because of wide state-by-state variation in the way felony offenses are defined. Eighteen states impose sentences up to 10 years; seven impose sentences between 11 and 20 years; and five impose sentences of greater than 20 years. In the remaining three states, maximum sentencing could not be quantified due to the broad judicial discretion set forth under the law (Table 1).

\section{Defenses}

Twenty-four states criminalize sexual behavior and/or needle-sharing when an individual has failed to disclose that he or she has HIV (Table 1). In 16 of these 24 states, lack of disclosure is an element of the crime itself, placing the burden of proof on the prosecution. In the other eight states, disclosure is an affirmative defense to the crime. 


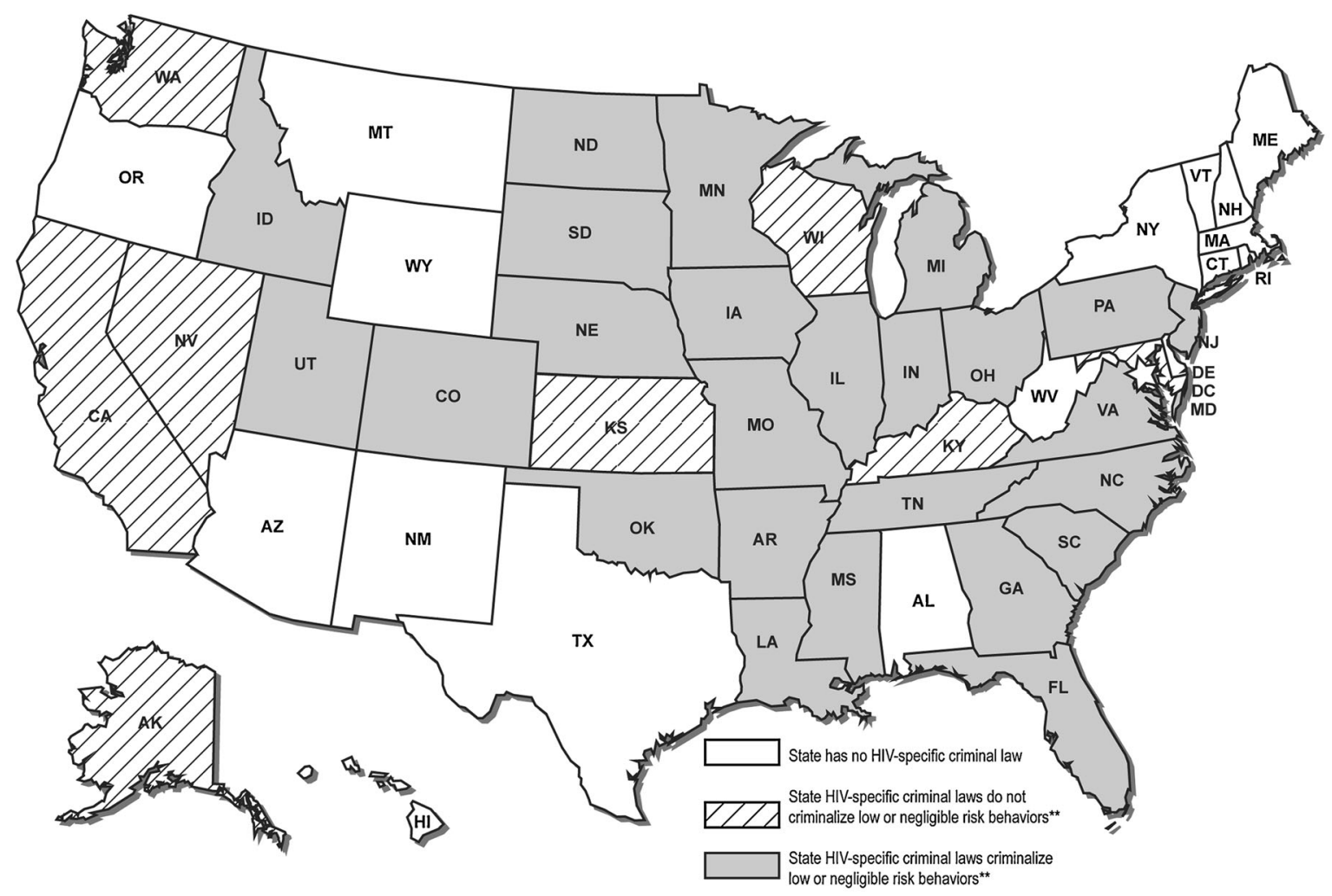

* In some states, very general language about sexual contact or sexual conduct would include oral, vaginal, or anal sex even though not explicitly defined

**Low/negligible risk as used in this figure includes oral sex, biting/spitting/throwing bodily fluids, and mutual masturbation

The information presented here does not constitute legal advice and does not represent the legal views of the Centers for Disease Control and Prevention, the Department of Health and Human Services, or the Department of Justice, nor is it a comprehensive analysis of all legal provisions that could possibly implicate the criminalization of potential HIV exposure. Rather, this information provides a state-specific snapshot of HIV-specific criminal laws. This information is subject to change and final determination of state level characteristics of the law can only be made by a given state's legal counsel. Use of any provision herein should be contemplated only in conjunction with advice from legal counsel

Fig. 2 U.S. states* with HIV-specific criminal laws-1986-2011

An affirmative defense in this context requires the defendant to prove disclosure of HIV-positive status, even though evidence of such disclosure during a sexual encounter and/or needle-sharing may be limited. Disclosure as a defense is unavailable to defendants charged with other criminalized behaviors such as prostitution or blood/tissue/fluid donation. Condom use is rarely addressed; only four states designate condom use as a defense to criminal liability.

\section{Discussion}

Thirty-three states currently have HIV-specific criminal laws. Most of these laws were passed before the widespread availability of ART had dramatically reduced deaths due to AIDS [29] and also before the knowledge that ART reduces HIV transmission risk. The impact of effective HIV prevention measures is now well understood. For example, ART reduced the likelihood of sexual transmission of HIV by up to $96 \%$ in a randomized trial [30], consistent condom use reduced heterosexual HIV transmission by $80 \%$ in a systematic review [31], and PrEP has been shown to have an efficacy of preventing HIV transmission of $44 \%$ in men who have sex with men [32] and at least $67 \%$ in heterosexual couples [33].

The number of prosecutions, arrests, and instances where HIV-specific criminal laws are used to induce plea agreements is unknown. Because state-level prosecution and arrest data are not readily available in any national legal database, the societal impact of these laws may be underestimated since many prosecutions lead to plea agreements, and most cases that go to trial are not reduced to written, published opinions. One illustrative list of HIV criminalization cases compiled 186 arrests and/or prosecutions from 2008 through January 2014, of which approximately $80 \%$ appear to have occurred under HIVspecific criminal laws. The remainder occurred under general criminal laws, mostly in states without HIV-specific criminal laws; there were no reported cases of 
prosecution under a general sexually transmitted disease or communicable disease law [34].

\section{Transmission Risk of Criminalized Behaviors}

The risk of acquiring HIV varies widely by route of exposure [24]. Many HIV-specific criminal laws group a number of behaviors together without accounting for that variation. For example, there are no documented cases of HIV transmission from spitting, while receptive anal intercourse has the highest per sexual act transmission risk [24]. Nevertheless, many state laws criminalize both high risk behaviors and low or negligible risk behaviors. Further, few of the laws take into account the fact that HIV prevention measures have been shown to substantially reduce the likelihood of HIV transmission.

\section{Knowledge of Laws}

Laws can be effective policy interventions if persons are aware of the laws, expect some level of enforcement, and if awareness influences their behaviors, in this case by reducing certain behaviors and/or increasing disclosure. Policy considerations regarding the effect of HIV-specific criminal laws generally assume widespread knowledge among persons who may be affected by the laws. In general, there is little data on how widespread the knowledge of laws that affect HIV prevention actually is. In the early 1990s, many states had passed laws to implement name-based HIV surveillance (the norm for infectious disease public health surveillance) to improve HIV prevention and epidemic tracking. A widely held community concern was that persons at risk for HIV had high levels of knowledge of the laws and the laws would deter persons from seeking HIV testing. However, a multistate study found that only $15 \%$ of participants could correctly identify their state law, and that name-based HIV surveillance was not associated with deterrence to testing [35]. Public health surveillance laws are relevant to different populations than those subject to HIV-specific criminal laws, but the context of a widely contested public policy is similar. These data suggest that high levels of knowledge of HIV-specific criminal laws and correct understanding of the content of the laws should not be assumed. These data further suggest that public health practice considerations focus on the known public health implications of these laws.

Levels of knowledge of HIV-specific criminal laws among persons who have HIV are not well known. A study conducted among persons recruited through AIDS Services Organizations in Michigan found that knowledge and understanding of the state's HIV exposure law was high
(76\% of those surveyed) [36]. However, Michigan state policy requires discussion of the state law at the HIV posttest counseling session at publicly funded HIV counseling and testing centers or when a person gets linked to care through federally funded case managers; the majority of newly diagnosed persons in Michigan would interact with public health system at one or both settings. Because of these policies, the level of knowledge of HIV-specific criminal laws in Michigan may not be indicative of knowledge in other states. Recent data from another study conducted through networks of community-based organizations in New Jersey found that $51 \%$ of persons living with HIV were aware of New Jersey's HIV-specific criminal law [20].

\section{Implications for Partner Notification}

Partner services programs are a broad array of services that should be offered to persons with HIV and their partners. Disclosure of HIV status to sexual and needle-sharing partners is an essential element of CDC's recommendations for partner services programs [23]. The degree to which HIV-specific criminal laws affect disclosure rates is unknown. The legal framework within which state-level partner services programs operate affects how these services balance the societal interests of legal and public health authorities, persons living with HIV, their partners, and the larger community. A critical function of partner services programs is partner notification (by the partner services program), and two key elements of partner notification are confidentiality and voluntary participation [37]. HIV-specific criminal laws could be a potential barrier to successful operation of these programs if they undermine either element. In 2008 guidelines, CDC acknowledged the potential interplay between HIV-specific criminal laws and state-specific partner notification programs and advised that program managers "should be aware of the applicable laws regarding criminal transmission and exposure in their jurisdictions" and that they should "consult with the legal counsel of their agency to gain a thorough understanding of the legal framework in which their specific programs operate, including their own legal authorities and those of other agencies (e.g., law enforcement)" [23]. These recommendations also advised program managers to coordinate with legal authorities in specific cases of potential HIV exposure or transmission. Persons with newly diagnosed HIV are also newly aware of their infection and thus not culpable under the law for non-disclosure to prior partners. Because of this, it is unlikely that HIV-specific criminal laws have a substantial impact on a newly diagnosed person's willingness to participate in notification of past partners. 
Reducing Unintended Consequences of HIV-Specific Criminal Laws and Alternatives to Current Approaches

The public health objective of increasing disclosure rates among persons living with HIV through the vehicle of HIV-specific criminal laws could have unintended consequences, such as intimate partner violence (domestic violence), following disclosure of HIV status. For example, an individual already living with intimate partner violence who tests positive for HIV may be left with a choice between disclosing that diagnosis and risking being subjected to further violence as a result, or not disclosing that diagnosis and risking prosecution for not disclosing that status. The general lack of evidence that HIV-specific criminal laws have reduced HIV transmission has led some authors to suggest that any negative effects of these laws-even if small-are not worth the risk [15]. Other authors have proposed restructuring current laws and limiting them to enhancement of serious sex crimes, such as sexual assault (including sex with minors); including only those behaviors that pose a high risk of HIV transmission; and requiring a clear intent to harm [7]. Another proposed approach is to forgo all use of HIV-specific criminal laws and instead rely on general criminal laws to prosecute only those cases of clear, intentional transmission [10]. In any of these approaches, prosecuting officials could consult with local public health officials to determine whether a public health intervention, rather than criminal prosecution, would be more beneficial in curbing risk behaviors.

\section{Conclusions}

HIV-specific criminal laws continue to be an area of public debate. Indeed, in May 2013 federal legislation (H.R. 1843: Repeal HIV Discrimination Act of 2013) [38] was introduced in the U.S. House of Representatives to facilitate federal, state, and local stakeholder review of these laws. Thirty-three states have HIV-specific criminal laws in place, and enactment of new laws has declined over time. Regardless, many laws do not distinguish between behaviors that pose higher, lower, or negligible HIV transmission risk and rarely take into account factors that alter transmission risk, such as condom use, ART, or PrEP. These prevention measures that alter transmission risk are now widely available through HIV prevention and treatment programs nationwide. Given that HIV-specific criminal laws may have wide-ranging social implicationsincluding (but not limited to) the perpetuation of misinformation regarding modes of HIV transmission-states are encouraged to utilize the findings of this paper as a basis to re-examine those laws, assess the laws' alignment with current evidence regarding HIV transmission risk, and consider whether current laws are the best vehicle to achieve their intended purposes.

Acknowledgments All authors contributed to the analysis and interpretation of study data and have no conflicts of interest. All coauthors were employees of the U.S. Centers for Disease Control or the U.S. Department of Justice while contributing to this manuscript and no non-federal resources were used in development of this manuscript.

\section{Appendix}

State-by-state compilation of HIV-specific laws ${ }^{1}$

\begin{tabular}{|c|c|}
\hline State & $\operatorname{Law}(\mathrm{s})$ \\
\hline Alabama & No HIV-specific criminal laws \\
\hline Alaska & $\begin{array}{l}\text { Alaska Stat. § 12.55.155(C)(33) (2006) (sentence } \\
\text { enhancement) }\end{array}$ \\
\hline Arizona & No HIV-specific criminal laws \\
\hline Arkansas & $\begin{array}{l}\text { Ark. Code Ann. § 5-14-123 (1989) (sexual } \\
\text { exposure; donation of blood, tissues, and fluids) }\end{array}$ \\
\hline California & $\begin{array}{l}\text { Cal. Health \& Safety Code } \S 1621.5 \text { (1988) } \\
\text { (donation of blood, tissues, and fluids) Cal. Health } \\
\& \text { Safety Code } \S 120291 \text { (1998) (sexual exposure) } \\
\text { Cal. Penal Code } \S 647 f \text { (1988) (solicitation/ } \\
\text { prostitution) Cal. Penal Code } \S 12022.85 \text { (1988) } \\
\text { (sentence enhancement) }\end{array}$ \\
\hline Colorado & $\begin{array}{l}\text { Colo. Rev. Stat. } \S 18-3-414.5 \text { (2010) \& } \\
\S 18-1.3-1004(d)(1999) \text { (sentence enhancement) } \\
\text { Colo. Rev. Stat. } § 18-7-201.7 \text { (1990) } \\
\text { (prostitution) Colo. Rev. Stat. } § 18-7-205.7 \\
\text { (1990) (solicitation) }\end{array}$ \\
\hline Connecticut & No HIV-specific criminal laws \\
\hline Delaware & No HIV-specific criminal laws \\
\hline $\begin{array}{l}\text { District of } \\
\text { Columbia }\end{array}$ & No HIV-specific criminal laws \\
\hline Florida & $\begin{array}{l}\text { Fla. Stat. Ann. } § 381.0041(11)(b) \text { (1988) (donation } \\
\text { of blood, tissues, and fluids) Fla. Stat. Ann. } \\
\S 384.24(2)(1986) \text { (sexual exposure) Fla. Stat. } \\
\text { Ann. } § 775.0877 \text { (1993) (sentence enhancement) } \\
\text { Fla. Stat. Ann. } § 796.08(5) \text { (1986) (prostitution) }\end{array}$ \\
\hline Georgia & $\begin{array}{l}\text { O.C.G.A. } § 16-5-60(c)(1988) \text { (sexual exposure; } \\
\text { needle-sharing; prostitution/solicitation; donation } \\
\text { of blood, tissues, and fluids) O.C.G.A. } \\
\S 16-5-60(\text { d) (2003) (biting/spitting/throwing) }\end{array}$ \\
\hline Hawaii & No HIV-specific criminal laws \\
\hline Idaho & $\begin{array}{l}\text { Idaho Code Ann. § 39-608 (1988) (sexual exposure; } \\
\text { needle-sharing; donation of blood, tissues, and } \\
\text { fluids) }\end{array}$ \\
\hline Illinois & $\begin{array}{l}720 \text { Ill. Comp. Stat. } § 5 / 12-5.01 \text { (1989) (sexual } \\
\text { exposure; needle-sharing; donation of blood, } \\
\text { tissues, and fluids) }\end{array}$ \\
\hline
\end{tabular}


Appendix continued

\begin{tabular}{|c|c|}
\hline State & $\operatorname{Law}(\mathrm{s})$ \\
\hline \multirow[t]{5}{*}{ Indiana } & $\begin{array}{l}\text { Indiana Code } \S 16-41-7-1 \text { (1993) (sexual exposure; } \\
\text { needle-sharing) }\end{array}$ \\
\hline & Indiana Code $\S 16-41-14-17$ (1993) (semen donation) \\
\hline & $\begin{array}{l}\text { Indiana Code } \S 35-42-1-7 \text { (b) \& (c) (1988) (blood } \\
\text { donation) }\end{array}$ \\
\hline & $\begin{array}{l}\text { Indiana Code } \S 35-42-2-6(\mathrm{e}) \&(\mathrm{f}) \text { (1995) (battery by } \\
\text { body waste against law enforcement \& lay persons) }\end{array}$ \\
\hline & $\begin{array}{l}\text { Ind. Code } \$ 35-45-16-2(a) \& \text { (b), (c) \& (d) (2002) } \\
\quad \text { (malicious mischief; malicious mischief with food) }\end{array}$ \\
\hline Iowa & $\begin{array}{l}\text { Iowa Code Ann. } § 709 \text { C.1 (1998) (sexual exposure; } \\
\text { donation of blood, tissues, and fluids; needle- } \\
\text { sharing) }\end{array}$ \\
\hline Kansas & $\begin{array}{l}\text { Kan. Stat. Ann. } § 21-3435 \text { (1992) (sexual exposure; } \\
\text { donation of blood, tissues, and fluids; needle- } \\
\text { sharing) }\end{array}$ \\
\hline \multirow[t]{2}{*}{ Kentucky } & $\begin{array}{l}\text { Ky. Rev. Stat. Ann. } § 311.990(24) \text { (b) (1990) (donation } \\
\text { of blood, tissues, and fluids) }\end{array}$ \\
\hline & $\begin{array}{l}\text { Ky. Rev. Stat. Ann. § 529.090(3) \& (4) (1990) } \\
\text { (prostitution) }\end{array}$ \\
\hline Louisiana & $\begin{array}{l}\text { La. Rev. Stat. Ann. § 14:43.5 (1987) (sexual exposure } \\
\text { biting/spitting/throwing) }\end{array}$ \\
\hline Maine & No HIV-specific criminal laws \\
\hline Maryland & $\begin{array}{l}\text { Md. Code Ann., Health-Gen. § 18-601.1 (1989) } \\
\text { (knowing transfer of HIV) }\end{array}$ \\
\hline Massachusetts & No HIV-specific criminal laws \\
\hline Michigan & $\begin{array}{l}\text { Mich. Comp. Laws Ann. § } 333.5210 \text { (1988) (sexual } \\
\text { exposure) Mich. Comp. Laws Ann } § 333.11101 \\
\text { (1988) (donation of blood, tissues, and fluids) }\end{array}$ \\
\hline Minnesota & $\begin{array}{l}\text { Minn. Stat. Ann. } \S 609.2241 \text { (1995) (sexual exposure } \\
\text { donation of blood, tissues, and fluids; needle- } \\
\text { sharing) }\end{array}$ \\
\hline Mississippi & $\begin{array}{l}\text { Miss. Code Ann. § 97-27-14(1) (2004) (knowing } \\
\text { exposure) Miss. Code Ann. § 97-27-14(2) (2004) } \\
\text { (biting/spitting/throwing) }\end{array}$ \\
\hline Missouri & $\begin{array}{l}\text { Mo. Ann. Stat. § } 191.677 \text { (1988) (donation of blood, } \\
\text { tissues, and fluids; sexual exposure; needle-sharing) } \\
\text { Mo. Ann. Stat. § } 565.085 \text { (2005) (biting/spitting/ } \\
\text { throwing) Mo. Ann. Stat. § 567.020 (2002) } \\
\text { (prostitution) }\end{array}$ \\
\hline Montana & No HIV-specific criminal laws \\
\hline Nebraska & $\begin{array}{l}\text { Neb. Rev. Stat. } § 28-101 \text { (2011) (biting/spitting/ } \\
\text { throwing at corrections officer) }\end{array}$ \\
\hline Nevada & $\begin{array}{l}\text { Nev. Rev. Stat. } § 201.205 \text { (1993) (sexual exposure) } \\
\text { Nev. Rev. Stat. } § 201.358 \text { (1987) (prostitution \& } \\
\text { solicitation) Nev. Rev. Stat. § 441A.300 (1989) } \\
\text { (knowing exposure) }\end{array}$ \\
\hline $\begin{array}{l}\text { New } \\
\text { Hampshire }\end{array}$ & No HIV-specific criminal laws \\
\hline New Jersey & N.J. Stat. Ann. § 2C:34-5 (1997) (sexual exposure) \\
\hline New Mexico & No HIV-specific criminal laws \\
\hline New York & No HIV-specific criminal laws \\
\hline $\begin{array}{l}\text { North } \\
\text { Carolina }\end{array}$ & $\begin{array}{l}\text { 10A N.C. Admin. Code 41A.0202 (1988) (sexual } \\
\text { exposure; needle-sharing; donation of blood, tissues } \\
\text { and fluids) }\end{array}$ \\
\hline North Dakota & $\begin{array}{l}\text { N.D. Cent. Code } \$ 12.1-20-17 \text { (1989) (sexual } \\
\text { exposure; needle-sharing) }\end{array}$ \\
\hline
\end{tabular}

Appendix continued

\begin{tabular}{|c|c|}
\hline State & Law(s) \\
\hline Ohio & $\begin{array}{l}\text { Ohio Rev. Code Ann. § } 2903.11 \text { (1999) (sexual } \\
\text { exposure) Ohio Rev. Code Ann. § 2907.24 (1996) } \\
\text { (solicitation) Ohio Rev. Code Ann. § } 2907.25 \text { (1996) } \\
\text { (prostitution) Ohio Rev. Code Ann. § 2907.241 } \\
\text { (1996) (loitering to commit prostitution) Ohio Rev. } \\
\text { Code Ann. § 2921.38 (1997) (biting/spitting/ } \\
\text { throwing) Ohio Rev. Code Ann. § 2927.13 (1988) } \\
\text { (donation of blood, tissues, and fluids) }\end{array}$ \\
\hline Oklahoma & $\begin{array}{l}\text { Okla. Stat. Ann. tit. 21, } \S 1031 \text { (1991) (prostitution) } \\
\text { Okla. Stat. Ann. tit. 21, } \S 1192.1 \text { (1988) (sexual } \\
\text { exposure; needle-sharing) }\end{array}$ \\
\hline Oregon & No HIV-specific criminal laws \\
\hline Pennsylvania & $\begin{array}{l}18 \text { Pa. Cons. Stat. Ann. } § 2703 \text { (1998) (biting/spitting/ } \\
\text { throwing) } 18 \text { Pa. Cons. Stat. Ann. § } 2704 \text { (1998) } \\
\text { (biting/spitting/throwing by life prisoner or death row } \\
\text { inmate) } 18 \text { Pa. Cons. Stat. Ann. § } 5902 \text { (1995) } \\
\text { (prostitution \& solicitation) }\end{array}$ \\
\hline Rhode Island & No HIV-specific laws \\
\hline $\begin{array}{l}\text { South } \\
\text { Carolina }\end{array}$ & $\begin{array}{l}\text { S.C. Code Ann. § 24-13-470 (1997) (biting/spitting/ } \\
\text { throwing) S.C. Code Ann. § 44-29-145 (1988) (sexual } \\
\text { exposure; prostitution; donation of blood, tissues, and } \\
\text { fluids; needle-sharing) }\end{array}$ \\
\hline $\begin{array}{l}\text { South } \\
\text { Dakota }\end{array}$ & $\begin{array}{l}\text { S.D. Codified Laws } \S 22-18-31 \text { (2000) (sexual } \\
\text { exposure; donation of blood, tissues, and fluids; } \\
\text { needle-sharing; biting/spitting/throwing) }\end{array}$ \\
\hline Tennessee & $\begin{array}{l}\text { Tenn. Code Ann. § 39-13-109 (1994) (sexual exposure; } \\
\text { donation of blood, tissues, and fluids; needle-sharing) } \\
\text { Tenn. Code Ann. § 39-13-516 (1991) (prostitution) } \\
\text { Tenn. Code Ann. § 68-32-104 (1986) (donation of } \\
\text { blood, tissues, and fluids) }\end{array}$ \\
\hline Texas & No HIV-specific criminal laws \\
\hline Utah & $\begin{array}{l}\text { Utah Code Ann. § 76-5-102.6 (1992) (biting/spitting/ } \\
\text { throwing) Utah Code Ann. § 76-10-1309 (1993) } \\
\text { (prostitution \& solicitation) }\end{array}$ \\
\hline Vermont & No HIV-specific criminal laws \\
\hline Virginia & $\begin{array}{l}\text { Va. Code Ann. § 18.2-67.4:1(A) \& (B) (2000) (sexual } \\
\text { exposure) Va. Code Ann. } § 32.1-289.2 \text { (1989) } \\
\text { (donation of blood, tissues, and fluids) }\end{array}$ \\
\hline Washington & $\begin{array}{l}\text { Wash. Rev. Code Ann. § 9A.36.011 (1986) (knowing } \\
\text { exposure) }\end{array}$ \\
\hline $\begin{array}{l}\text { West } \\
\text { Virginia }\end{array}$ & No HIV-specific criminal laws \\
\hline Wisconsin & $\begin{array}{l}\text { Wis. Stat. Ann. § } 973.017 \text { (2002) (sentence } \\
\text { enhancement) }\end{array}$ \\
\hline Wyoming & No HIV-specific criminal laws \\
\hline
\end{tabular}

The information presented here does not constitute legal advice and does not represent the legal views of the Centers for Disease Control and Prevention, the Department of Health and Human Services, or the Department of Justice, nor is it a comprehensive analysis of all legal provisions that could possibly implicate the criminalization of potential HIV exposure. Rather, this information provides a state-specific snapshot of HIV-specific criminal laws. This information is subject to change and final determination of state level characteristics of the law can only be made by a given state's legal counsel. Use of any provision herein should be contemplated only in conjunction with advice from legal counsel

${ }^{1}$ The year listed for each law indicates the enactment date (including the date of HIV-specific amendments) 


\section{References}

1. Gable L, Gostin L, Hodge JG. A global assessment of the role of law in the HIV/AIDS pandemic. Public Health. 2009;123:260-4.

2. Lazzarini Z, Klitzman R. HIV and the law: integrating law, policy and social epidemiology. J Law Med Ethics. 2002;30(4): 533-47.

3. Neff S, Goldschmidt R. Centers for Disease Control and Prevention 2006 human immunodeficiency virus testing recommendations and state testing laws. JAMA. 2011;305(17):1767-8.

4. Cal. Health and Safety Code Section 121025, 2011. http://www. leginfo.ca.gov/cgi-bin/displaycode?section=hsc\&group $=121001$ 122000\&file $=121025-121035$. Accessed 3 Mar 2014.

5. Public Law 104-191: Health Insurance Portability and Accountability Act of 1996. http://aspe.hhs.gov/admnsimp/pl104191.htm. Accessed 3 Mar 2014.

6. O'Toole EM. HIV-specific crime legislation: targeting an epidemic for criminal prosecution. J L Health. 1995-1996;10:183-208.

7. Wolf LE, Vezina R. Crime and punishment: is there a role for criminal law in HIV prevention policy? Whittier L. Rev. 2004;25:821-86.

8. Lazzarini Z, Bray S, Burris S. Evaluating the impact of criminal laws on HIV risk behavior. J Law Med Ethics. 2002;30(2):239-53.

9. Burris S, Cameron E. The case against criminalization of HIV transmission. JAMA. 2008;300(5):578-81.

10. UNAIDS. UNAIDS policy brief: criminalization of HIV transmission. 2008. http://data.unaids.org/pub/basedocument/2008/ 20080731_jc1513_policy_criminalization_en.pdf. Accessed 3 Mar 2014.

11. Bennett-Carlson R, Faria D, Hanssens C. Ending and defending against HIV criminalization: a manual for advocates Vol. 1. The Center for HIV Law \& Policy. 2010. http://hivlawandpolicy.org/ resources/ending-and-defending-against-hiv-criminalization-stateand-federal-laws-and-prosecutions. Accessed 3 Mar 2014.

12. Wapner J. Why we need to stop treating HIV victims like criminals. The Atlantic. 2011; March 11. http://www.theatlantic. com/life/archive/2011/03/why-we-need-to-stop-treating-hiv-vic tims-like-criminals/72838/. Accessed 3 Mar 2014.

13. UNAIDS. Criminal law, public health and HIV transmission: a policy options paper. 2002. http://data.unaids.org/publications/ IRC-pub02/jc733-criminallaw_en.pdf. Accessed 3 Mar 2014.

14. Galletly CL, Pinkerton SD. Conflicting messages: how criminal HIV disclosure laws undermine public health efforts to control the spread of HIV. AIDS Behav. 2006;10:451-61.

15. Burris S, Beletsky L, Burleson J, Case P, Lazzarini Z. Do criminal laws influence HIV risk behavior? An empirical trial. Ariz St L J. 2007;39:467-517.

16. White House. Report of the presidential commission on the human immunodeficiency virus epidemic. 1988. http://archive. org/details/reportofpresiden00pres. Accessed 3 Mar 2014.

17. Public Law 101-381: Ryan White Comprehensive AIDS Resources Emergency Act of 1990. http://history.nih.gov/ research/downloads/PL101-381.pdf. Accessed 3 Mar 2014.

18. White House. National HIV/AIDS strategy for the United States. 2010. http://www.whitehouse.gov/administration/eop/onap/nhas. Accessed 3 Mar 2014.

19. Heywood T. 'Past time' to review HIV criminal laws, says former presidential commission member. 2011. The American Independent. http://americanindependent.com/218098/\%e2\%80\%98pasttime $\%$ e $\% 80 \% 99$-to-review-hiv-criminal-laws-says-former-pre sidential-commission-member. Accessed 3 Mar 2014.
20. Galletly CL, Glasman LR, Pinkerton SD, DiFranceisco W. New Jersey's HIV exposure law and HIV-related attitudes, beliefs, and sexual and seropositive status disclosure behaviors of persons living with HIV. Am J Public Health. 2012;102(11):2135-40.

21. Horvath KJ, Weinmeyer R, Rosser S. Should it be illegal for HIV-positive persons to have unprotected sex without disclosure? An examination of attitudes among US men who have sex with men and the impact of state law. AIDS Care. 2010;22(10): 1221-8.

22. Galletly CL, Pinkerton SD. Preventing HIV transmission via HIV exposure laws: applying logic and mathematical modeling to compare statutory approaches to penalizing undisclosed exposure to HIV. J Law Med Ethics. 2008;36:577-84.

23. Centers for Disease Control and Prevention. Recommendations for partner services programs for HIV infection, syphilis, gonorrhea, and chlamydial infection. MMWR. 2008;57 (No. RR9): $1-83$.

24. Centers for Disease Control and Prevention. Fact sheet: HIV transmission risk. 2012. http://www.cdc.gov/hiv/law/pdf/HIV tranmsmision.pdf. Accessed 3 Mar 2014.

25. Burris S, Wagenaar AC, Swanson J, Ibraham JK, Wood J, Mello MM. Making the case for laws that improve health: a framework for public health law research. Milbank Q. 2010;88(2):169-210.

26. Burris S, Anderson E. The challenges of quantitative public health law research. Am J Prev Med. 2010;39(1):99-101.

27. Tremper C, Thomas S, Wagenaar AC. Measuring law for evaluation research. Evaluation Rev. 2010;34(3):242-66.

28. Md. Code Ann., Health-Gen. s. 18-601.1, 1989. http://law.justia. com/codes/maryland/2005/ghg/18-601.1.html. Accessed 3 Mar 2014.

29. Centers for Disease Control and Prevention. HIV SurveillanceUnited States, 1981-2008. MMWR. 2011;60(21):689-93.

30. Cohen MS, Chen YQ, McCauley M, et al. Prevention of HIV-1 infection with early antiretroviral therapy. NEJM. 2011;365(6): 493-505.

31. Weller SC, Davis-Beaty K. Condom effectiveness in reducing heterosexual HIV transmission. Cochran DB Syst Rev. Wiley and Sons, 2012.

32. Grant RM, Lama JR, Anderson PL, et al. Pre-exposure chemoprophylaxis for HIV prevention in men who have sex with men. NEJM. 2010;363(27):2587-99.

33. Baeten JM, Donnell D, Ndase NR, et al. Antiretroviral prophylaxis for HIV prevention in heterosexual men and women. NEJM. 2012;367(5):399-410.

34. The Center for HIV Law \& Policy. Prosecutions and arrests for HIV exposure in the United States, 2008-2014. http://www.hiv lawandpolicy.org/resources/view/456. Accessed 3 Mar 2014.

35. Hecht FM, Chesney MA, Lehman JS, et al. Does HIV reporting by name deter testing? AIDS. 2000;14(12):1801-8.

36. Galletly CL, Pinkerton SD, DiFranceisco W. A quantitative study of Michigan's criminal HIV exposure law. AIDS Care. 2012;24(2):174-9.

37. Gostin LO, Hodge JG. Piercing the veil of secrecy in HIV/AIDS and other sexually transmitted diseases: theories of privacy and disclosure in partner notification. Duke J Gender L Pol'y. 1998;5(9):9-88.

38. Lee B.US. H.R. 1843: REPEAL HIV Discrimination Act of 2013. https://www.govtrack.us/congress/bills/113/hr1843. Accessed 3 Mar 2014. 